\title{
THE APPLICATION OF ADSORBENT BENTONITE IN OXIDATIVE STRESS INDUCED BY PARAQUAT
}

\author{
IVANOVIĆ S*, BOROZAN SUNČICA*, JEZDIMIROVIĆ MILANKA*, ALEKSIĆ NEVENKA*, \\ MILOVANOVIĆ MIRJANA*, TOMAŠEVIĆ-ČANOVIĆ MAGDALENA** and ĐURĐEVIĆ ${ }^{* * \star *}$ \\ *Faculty of Veterinary Medicine, Belgrade; \\ **Institute for Technology of Nuclear and Other Raw Materials, Belgrade; \\ ***Military Medical Academy, Belgrade \\ (Received 2. February 2007)
}

The protective effect of bentonite (natural and synthetic) in oxidative stress induced by paraquat was studied on 32 adult male Wistar rats. The animals were divided into four groups $(n=8)$. The first group received only paraquat p.o. (via a gastric tube). An hour after administration of paraquat, the second and the third group were treated with natural and synthetic bentonite, respectively, while the fourth group was untreated (control). All three experimental groups were treated once a day, throughout 8 consecutive days. Blood samples were taken 0, 1, 4, 6 and 8 days after the beginning of the treatment.

Oxidative stress induced by paraquat was estimated by means of catalase activity (CAT - $\mathrm{mmol} / \mathrm{H}_{2} \mathrm{O}_{2} / \mathrm{min} / \mathrm{g} \mathrm{Hb}$ ) and malondialdehyde quantity (MDA - nmol/g Hb).

Oxidative stress proved to be significant an hour and 192 hours after the beginning of chronic intoxication by paraquat.

Both natural and synthetic bentonite expressed a protective action from oxidative stress in the period from $24 \mathrm{~h}$ to $144 \mathrm{~h}$ post application, acting through the external capacity of cationic exchange, which is known to be approximately $10 \%$. The absorption of paraquat depends on the size of the molecule and its polarisation and is performed by the mechanisms of ion exchange (ionic and electrostatic interaction). Nevertheless, both absorbents developed a significant protective effect (approximately $50 \%$ ) $1 \mathrm{~h}$ and $192 \mathrm{~h}$ after the first application of paraquat, indicating that these protectors act as molecular sieves and thus suppress the process of lipid peroxidation and the development of even more intensive oxidative stress.

Key words: bentonite, oxidative stress, paraquat

\section{INTRODUCTION}

Paraquat is a non-selective herbicide highly toxic for both animals and humans. Thousands of deaths occurred after ingestion (in humans often suicidal) or dermal exposure to paraquat (Pesticide Action Network - PAN, 2003). Both in acute and chronic intoxication primary injuries to mammals occur in the lungs, 
which selectively accumulate paraquat. Since there are no known pharmacological antagonists of paraquat and no chelating agents capable of binding the poison in the blood or other tissues, the management of paraquat poisoning has been directed towards the modification of the toxicokinetics of the poison by decreasing the absorption or decreasing the oxidant-induced cellular damage (Suntres, 2002).

The aim of the current investigation was to determine the influence of natural and synthetic bentonite as adsorbents in rats poisoned with paraquat. The influence of paraquat on red blood cells of rats in vivo was examined, i.e. the production of certain reactive oxygen species and their influence on lipid peroxidation in the membranes of red blood cells.

The high toxicity of paraquat is achieved by damaging the cell integrity due to highly reactive free radicals which emerge from redox cycling in the presence of molecular oxygen. Superoxide anionic radical $\left(\mathrm{O}_{2}{ }^{-}\right)$produced in the process of redox cycling of this herbicide transforms into hydrogen peroxide $\left(\mathrm{H}_{2} \mathrm{O}_{2}\right)$. The synthesized $\mathrm{O}_{2}{ }^{--}$and $\mathrm{H}_{2} \mathrm{O}_{2}$ use $\mathrm{NADPH}$, and in reaction with lipids produce lipid hydroperoxides which contribute to further lipid peroxidation. Lipid peroxidation decreases the fluidity of biological membranes, which results in higher permeability for bivalent ions and dramatical changes in ion-dependent processes.

The aim of the study was to investigate the mechanism of toxicity of paraquat after p.o. chronic intoxication in the dose of $25 \mathrm{mg} / \mathrm{kg}$. This was achieved by estimation of parameters of oxidative stress, which are the activity of the antioxidative enzyme CAT, and the level of lipid peroxidation via MDA measurments. In addition to this, the research on the protective effect of natural and synthetic bentonite in oxidative stress provoked by paraquat was carried out.

\section{MATERIALS AND METHODS}

The investigation was performed on 32 adult male Wistar rats (220-230 g bw). The animals were divided into 3 experimental and a control group $(n=8)$. Animals in experimental groups (I to III) were treated p.o., by a gastric tube, with paraquat ("Gramoxone", Syngenta Crop Protection, Basel, Switzerland, CAS number: 2074-50-2), in a dose of $25 \mathrm{mg} / \mathrm{kg}$ b.w. The first experimental group received only paraquat. The second experimental group was treated with $40 \%$ water suspension of natural bentonite in a volume of $10 \mathrm{ml} / \mathrm{kg} \mathrm{b.w}$. in the same manner (by gastric intubation), an hour after the administration of paraquat, while the third experimental group was treated with the same volume of synthetic bentonite. The fourth group was the untreated.

All three experimental groups were treated once a day, throughout 8 consecutive days. Blood was collected 1, 24, 96, 144 and 192 hours after the beginning of the treatment and treated with anticoagulant, sodium citrate $(3.8 \%$ $\mathrm{w} / \mathrm{v})$. Erythrocytes were separated by centrifugation (3000 rpm) and washed in saline three times, immediately followed by the estimation of the enzyme activities. 
The CAT activity was estimated by the method of Beutler. CAT degrades hydrogen peroxide, whose concentration can be measured directly by the decrease in the absorbance at $240 \mathrm{~nm}$ (Beutler, 1982).

The level of lipid peroxidation (LP) was assayed through the concentration of thiobarbituric acid as the reactive substance (TBARS) in the red blood cells according to Uchiyama and Mihara (Uchiyama and Mihara, 1978). Haemoglobin concentration was determined by the cyanmethemoglobin method (Drabkin and Austin, 1935).

\section{RESULTS}

In the current investigations on Wistar rats, after the application of paraquat (p.o., $25 \mathrm{mg} / \mathrm{kg}$ ), a positive correlation between the changes due to oxidative stress provoked by paraquat (i.e. between the activity of CAT, and the intensity of lipid peroxidation estimated through MDA concentration) was observed $1 \mathrm{~h}$ and $192 \mathrm{~h}$ after the beginning of the application of paraquat, in all treated groups.

The activity of CAT following intoxication with paraquat was increased, as well as the concentrations of $\mathrm{H}_{2} \mathrm{O}_{2}$ (Figures 1, 3 and 5).

A statistically significant increase in CAT activity was observed $1 \mathrm{~h}, 96 \mathrm{~h}$ and $192 \mathrm{~h}$ (Figures 1, 3 and 5, respectively) after paraquat application, compared with the activity of the enzyme $24 \mathrm{~h}(30.88 \%)$ and $144 \mathrm{~h}(36.27 \%)$ after the beginning of intoxication (Figures 2 and 4, respectively).

Natural and synthetic bentonite administered p.o. a dose of $4 \mathrm{~g} / \mathrm{kg} \mathrm{b.w.}$ significantly decreased the activity of CAT 1 and $192 \mathrm{~h}$ after application. Synthetic bentonite was more efficacious in decreasing the activity of the enzyme in comparison with natural bentonite.

An hour after administration of paraquat synthetic bentonite reduced CAT activity by $70.08 \%$ in comparison to animals treated only with paraquat, whilst the efficacy of natural bentonite was approximately half as high as that in the synthetic, decreasing the activity of CAT by $36 \%$ (Figure 1 ).

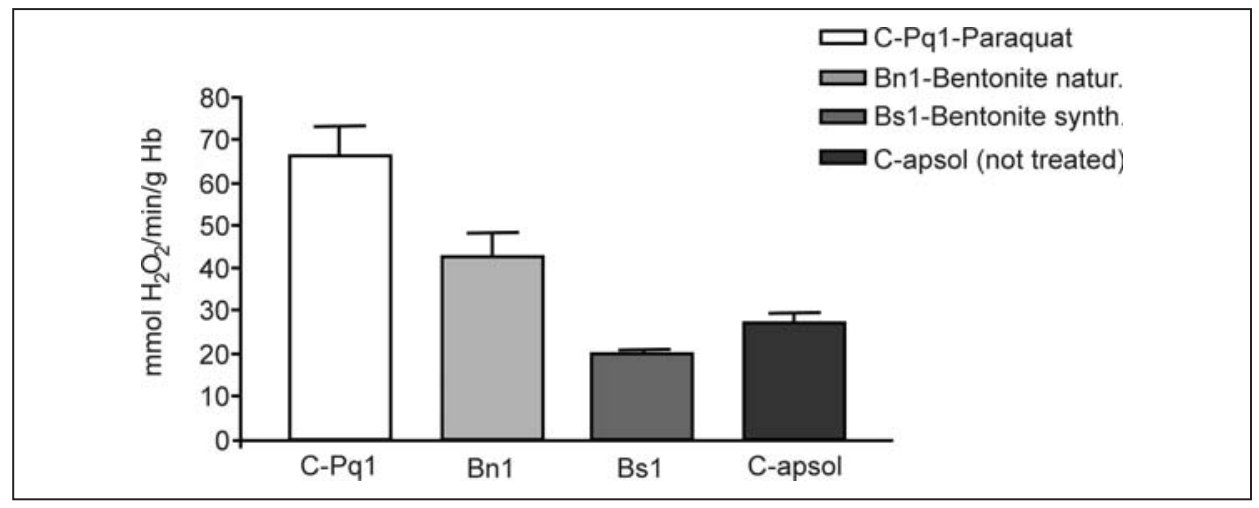

Figure 1. CAT activity on day 0 (1 hour after the beginning of treatment) 


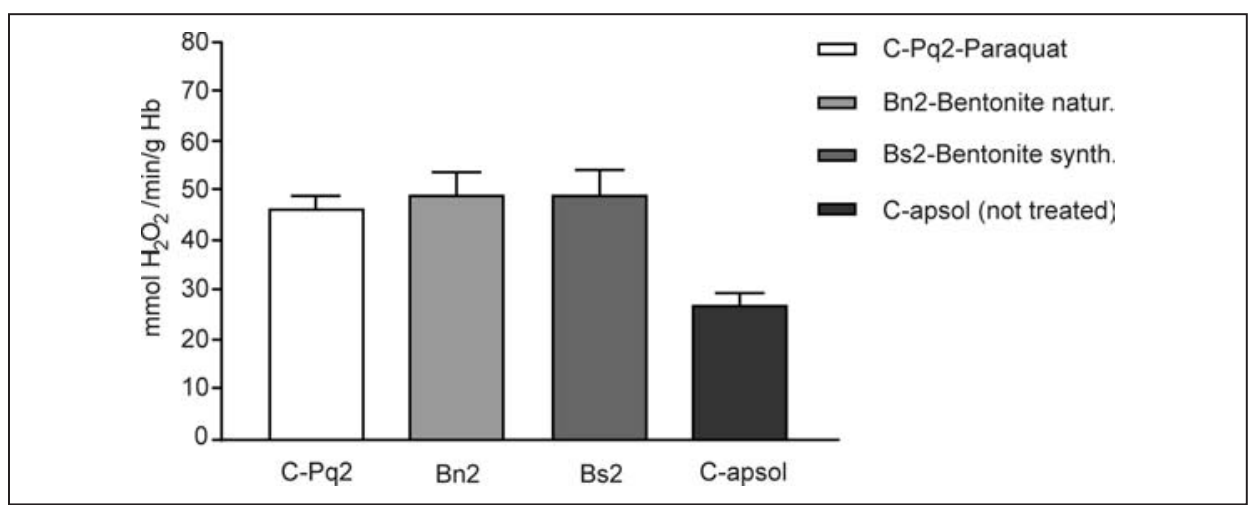

Figure 2. CAT activity 24 hours after the beginning of treatment

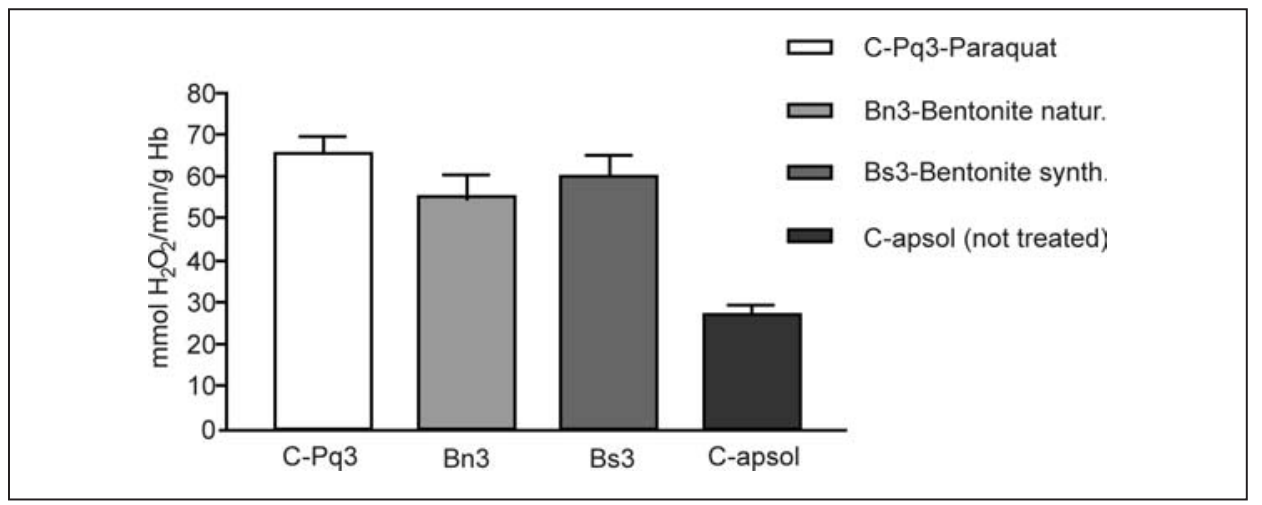

Figure 3. CAT activity 96 hours after the beginning of treatment

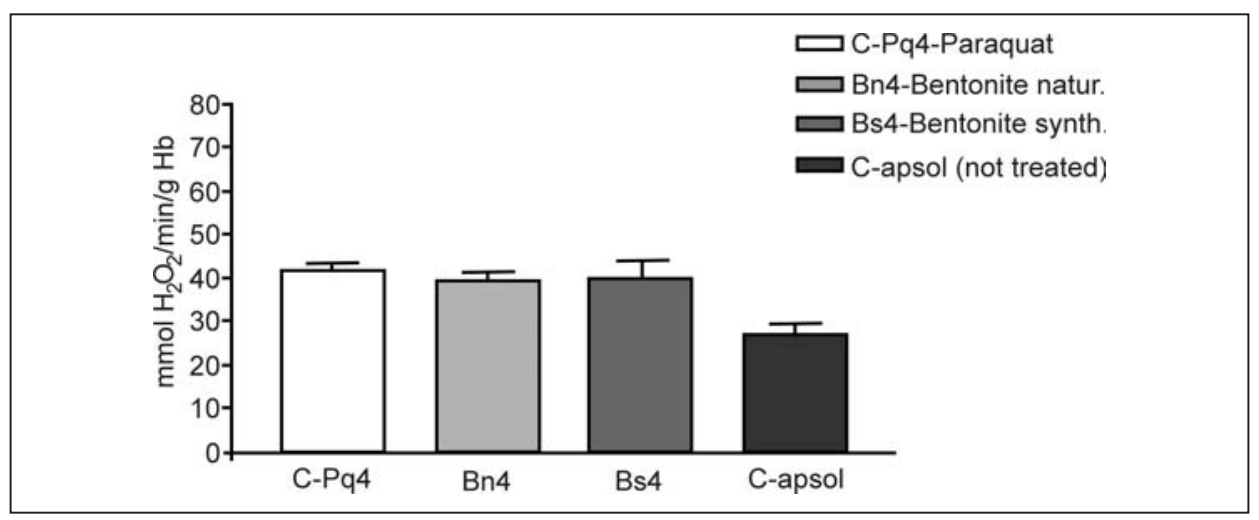

Figure 4. CAT activity 144 hours after the beginning of treatment 
Acta Veterinaria (Beograd), Vol. 57. No. 4, 329-340, 2007.

Ivanović $\mathrm{S}$ et al.: The application of adsorbent bentonite

in oxidative stress induced by paraquat

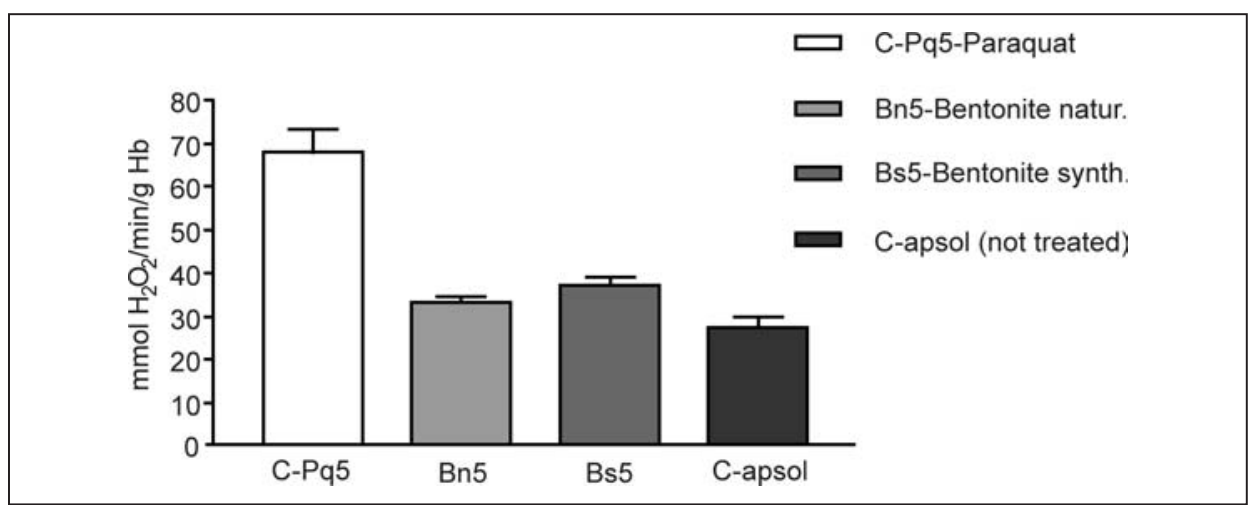

Figure 5. CAT activity 192 hours after the beginning of treatment

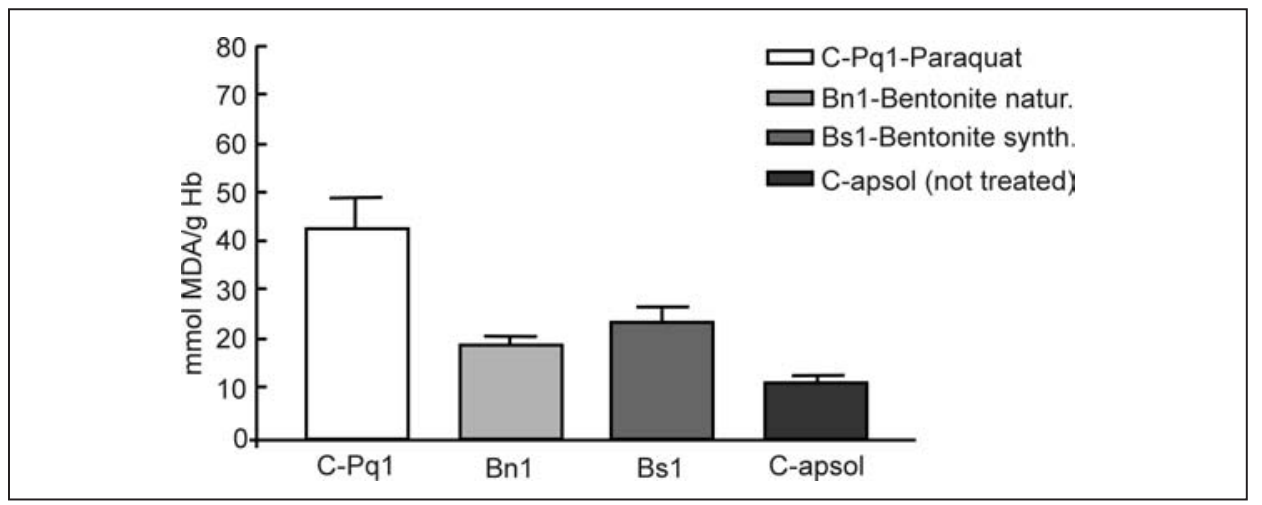

Figure 6. MDA 1 hour after beginning of treatment

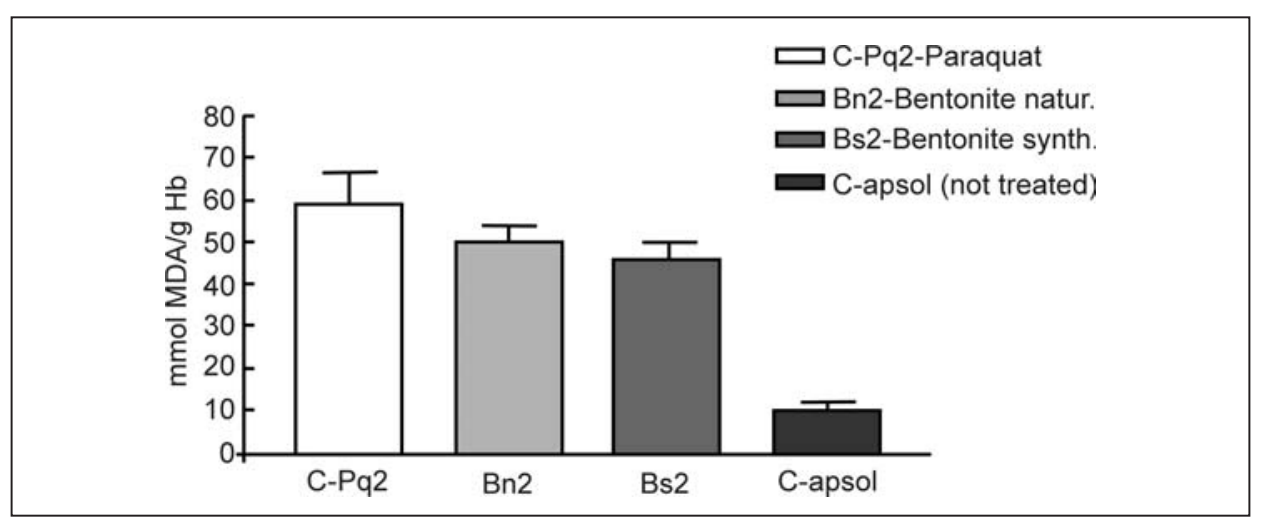

Figure 7. MDA 24 hours after beginning of treatment 
Both tested adsorbents decreased CAT activity with similar efficacy $192 \mathrm{~h}$ after application. Natural bentonite caused a decrease of $51.74 \%$ and the synthetic $46.04 \%$, compared with the activity of the enzyme in rats treated only with paraquat (Figure 5).

Neither natural nor synthetic bentonite influenced CAT activity significantly 24, 96 and $144 \mathrm{~h}$ after the beginning of paraquat application, in comparison to Group 1 (Figures 2, 3 and 4).

Paraquat induces the process of lipid peroxidation in erythrocytes producing various concentrations of MDA over time. In the initial phase of paraquat intoxication ( $1 \mathrm{~h}$ and $24 \mathrm{~h}$ after application) the concentration of MDA rose (Figures 6 and 7), which was followed by its decrease (Figures 8 and 9) and another increase in the terminal phase of intoxication (Figure 10).

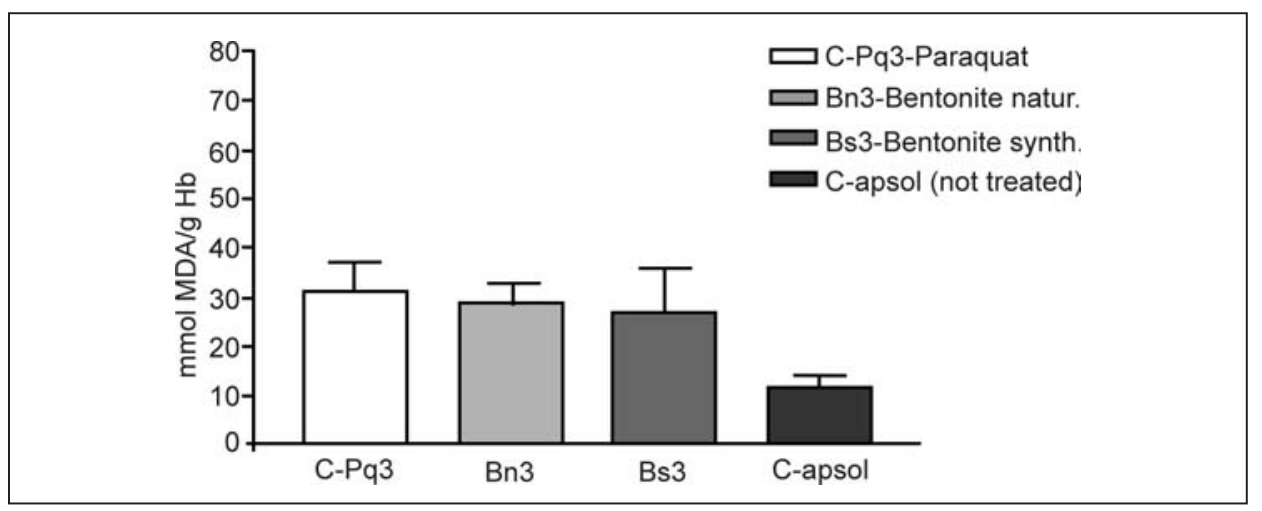

Figure 8. MDA 96 hours after beginning of treatment

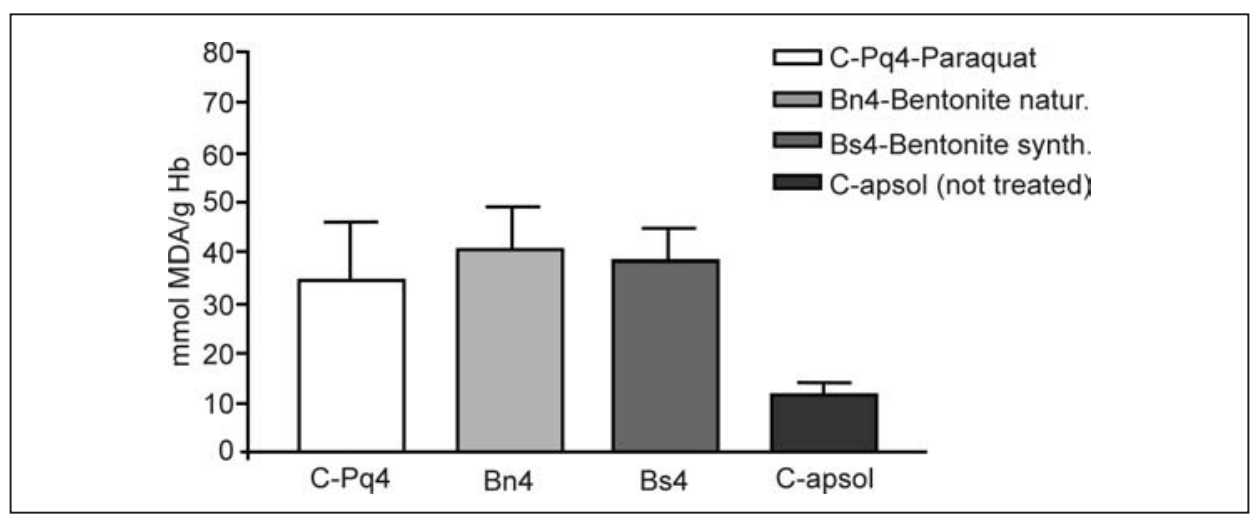

Figure 9. MDA 144 hours after beginning of treatment 
Acta Veterinaria (Beograd), Vol. 57. No. 4, 329-340, 2007.

Ivanović $S$ et al.: The application of adsorbent bentonite

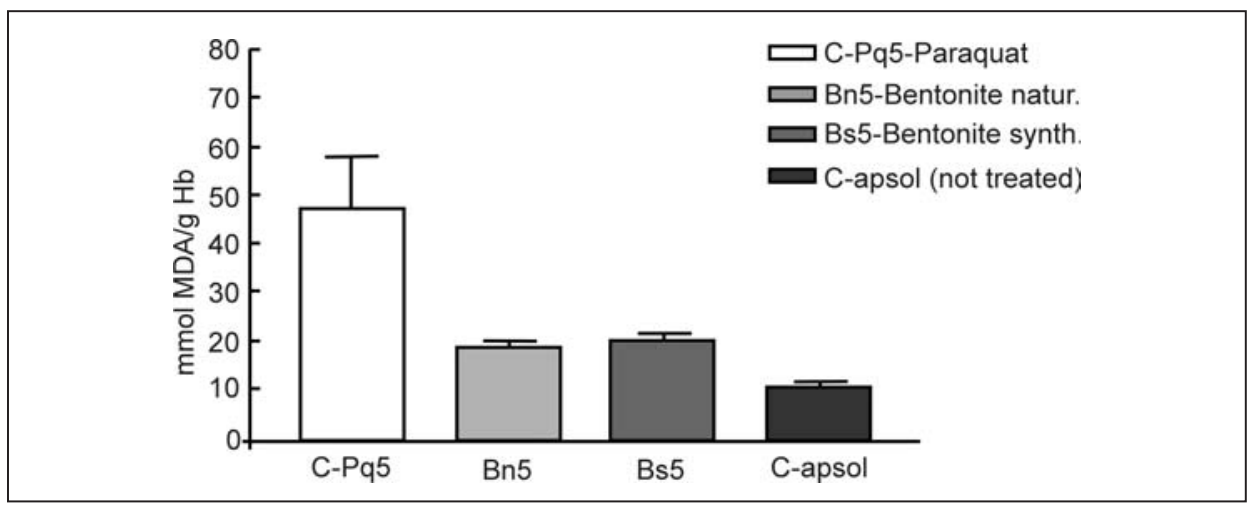

Figure 10. MDA 192 hours after beginning of treatment

\section{DISCUSSION}

Being a herbicide, paraquat binds irreversibly and for a long time to the treated soil. Having this in mind, it is logical to predict that certain minerals originating from the soil are capable of antagonizing, at least to some extent, the toxic effects of paraquat in poisoned animals and humans (Cope et al., 2004; Walcarius et al., 2004).

The adsorptive capacity of bentonite after poisoning with paraquat is proved and is approximately $5 \%$ (Okonek et al., 1982). However, the bentonite adsorptive capacity cited is not sufficiently protective in paraquat poisoning, thus additional therapy including active coal perfusion is inevitable (Lopez et al., 2002; Idid et al.,1996).

Besides paraquat, bentonites are capable of adsorbing aflatoxin B1 and unorganic anions which contaminate waste waters (Tomašević-Čanović Magdalena et al., 2001; Banat et al., 2000; Vujaković et al., 2003).

Bentonite is an aluminiosilicate mineral rich in canals and holes that can adsorb molecules and ions which measure less than the diameters of the holes. The adsorbtive selectivity depends mainly on the polarity of the molecules of toxic materials. Bentonites efficiently adsorb $\mathrm{H}_{2} \mathrm{O}, \mathrm{CO}_{2}, \mathrm{SO}_{2}, \mathrm{NO}_{2}$ and $\mathrm{H}_{2} \mathrm{~S}$. Besides the internal capacity of cationic exchange, bentonites are characterised by an external capacity of cationic exchange, representing the sum of exchangeable cations on the external surface of bentonite and is approximately $10 \%$ of the total capacity for cationic exchange.

The aim of the current investigation was to test the adsorbent-protective effect of bentonite in oxidative stress due to paraquat. Paraquat induces the production of free radicals and thus contributes to cell death. However, the precise mechanism of free radical production induced by this herbicide is unknown. This is the reason for the fact that investigations on metabolism and mechanisms of paraquat toxicity and the possibilities for protection against poisoning with this herbicide are still current. 
According to ample research and data it is supposed that the toxic effect of paraquat happens on the molecular level and is a result of free radical production in redox reactions (Bus and Gibson, 1984; Mollace et al., 2003).

In the presence of an electron donor, NADPH, and the enzyme cytochrome $\mathrm{P}-450$ NADPH reductase, the $\mathrm{PQ}^{2+}$ ion being highly electrophilic, is metabolised by monoelectron reduction in the cell into stabile monoionic cation radical $\mathrm{PQ} \cdot{ }^{+}$.

$$
\mathrm{PQ}^{2+}+\mathrm{NADPH} \longrightarrow \mathrm{PQ}^{+}+\mathrm{NADP}^{+}
$$

In aerobic conditions, $\mathrm{PQ}^{+}$reacts with oxygen and in the reaction of monoelectronic reduction it delivers its odd electron, thus leading to superoxide anionic radical $\left(\mathrm{O}_{2} \cdot{ }^{-}\right)$formation and $\mathrm{PQ} \cdot{ }^{+}$oxidation into $\mathrm{PQ}^{2+}$.

$$
\mathrm{PQ} \cdot{ }^{+}+\mathrm{O}_{2} \longrightarrow \mathrm{PQ}^{2+}+\mathrm{O}_{2} \cdot{ }^{-}
$$

In the presence of reduction equivalents, the regenerated $\mathrm{PQ}^{2+}$ ions are again reduced to monocation $\mathrm{PQ} \cdot{ }^{+}$radicals that repeatedly react with oxygen producing $\mathrm{O}_{2} \cdot{ }^{-}$.

The metabolic path of $\mathrm{O}_{2}{ }^{-}{ }^{-}$, highly depends on $\mathrm{pH}$ and can go towards reduction or oxidation expressing either its oxidative or antioxidative properties.

$$
\mathrm{O}_{2} \longleftarrow \mathrm{O}_{2} \cdot{ }^{-} \longrightarrow \mathrm{H}_{2} \mathrm{O}_{2}
$$

In protonic conditions (high concentrations of $\mathrm{H}^{+}$ions) in the presence of $\mathrm{Fe}^{3+}, \mathrm{Cu}^{2+}$, the superoxide anionic radical $\mathrm{O}_{2} \cdot^{-}$is oxygenized into molecular oxygen $\left(\mathrm{O}_{2}\right)$ (Liochev and Fridovich, 1994).

In aprotonic conditions (low concentation of $\mathrm{H}^{+}$ions), when oxidative stress is developed and the reserve of reduction equivalents of $\mathrm{NAD}(\mathrm{P}) \mathrm{H}$ is spent, i.e. when there is too much $\mathrm{NAD}(\mathrm{P})^{+}$, the reduction of $\mathrm{O}_{2}{ }^{-}$into $\mathrm{H}_{2} \mathrm{O}_{2}$ is favoured.

The synthesized peroxide is degraded by CAT. CAT ( $E C$ 1.11.1.6) is located in peroxisomes, quickly transforming high concentrations of $\mathrm{H}_{2} \mathrm{O}_{2}$ into molecular oxygen and water.

$$
2 \mathrm{H}_{2} \mathrm{O}_{2} \stackrel{\text { CAT }}{\longrightarrow} \mathrm{O}_{2}+2 \mathrm{H}_{2} \mathrm{O}
$$

This is a two-stage reaction and involves the binding of two molecules of hydrogen peroxide to CAT, thus there is a slight probability for the reaction to occur when the concentration of peroxide is low. CAT is a tetramer protein, with the active centre bound to four subunits comprising the haem group ( $\mathrm{Fe}^{3+}$ protoporfirin). Besides the haem, each subunit includes NADPH that stabilizes the enzyme (Mates et al., 1999).

The activity of CAT in paraquat intoxication accompanies the changes of hydrogen peroxide concentration. Statistically significant decrease in CAT activity was detected $24 \mathrm{~h}(30.88 \%)$ and $144 \mathrm{~h}(36.27 \%)$ after the beginning of paraquat administration, in comparison with the enzyme activity $1 \mathrm{~h}$ from the beginning of poisoning. The enzyme was possibly in some way inhibited or its capacity may 
have been significantly exhausted due to intensive elimination of $\mathrm{H}_{2} \mathrm{O}_{2}$ synthesized as a result of conjoined activity of $\mathrm{PQ} \cdot{ }^{+}$and $\mathrm{O}_{2} \cdot{ }^{-}$, in order to maintain the homeostatic mechanisms in cells after intoxication with PQ. The exhaustion of the enzymes involved in antioxidative protection (SOD, CAT, GR, GPx, etc.) that sequester the reactive products, as well as the decrease in NADPH and glutathione (electron donor), disturb the redox state in cells and promotes oxidative stress (Kono and Fridovich, 1982; Halliwell and Gutterdge, 1999). Oxidative stress due to continuous $\mathrm{O}_{2} \cdot{ }^{-}$production in redox reactions developed $192 \mathrm{~h}$ after the beginning of intoxication, consequently increasing the activity of CAT to $68.25 \pm 5.16 \mathrm{mmol} / \mathrm{min} / \mathrm{g} \mathrm{Hb}$ (Figure 5). The processes happening during paraquat redox cycling are irreversible and lead to cell death (Bus and Gibson, 1984).

In the presence of transition metals ( $\mathrm{Fe}$ or $\mathrm{Cu}$ ), superoxide anion radical $\mathrm{O}_{2}{ }^{-}$ transforms into hydrogen peroxide $\left(\mathrm{H}_{2} \mathrm{O}_{2}\right)$, a molecule with pronounced oxidative properties. The product of homolytic break of unstable connection in $\mathrm{H}_{2} \mathrm{O}_{2}(\mathrm{HO}$ $\mathrm{OH})$ is the hydroxil radical $(\mathrm{HO} \cdot)$, the most potent reactive radical, that instantly reacts with numerous cell macromolecules, including lipids, nucleic acids and proteins (Valko et al., 2006a; Valko et al., 2006b).

Hydrogen peroxide $\left(\mathrm{H}_{2} \mathrm{O}_{2}\right)$ via $\mathrm{HO}$. leads to peroxidation of polyunsaturated fatty acids (PUFAs), the constituents of cell membranes and membranes of cell organeles. In the terminal phase of lipid peroxidation malondialdehyde (MDA) is produced as one of the products of degradation of PUFAs. In the reaction of TBA with MDA a pink coloured complex is produced, whose adsorbance is measured at $535 \mathrm{~nm}$. The concentration of MDA indicates the level of lipid peroxidation (Uchida, 2003; Traverso et al., 2004).

In the present investigations, $1 \mathrm{~h}$ after the beginning of intoxication with paraquat, the process of lipid peroxidation was noticeable and statistically significant $(p<0.001)$. The increase in lipid peroxidation immediately after the beginning of intoxication was an expected indicator of activated aggressive, oxidative mechanisms (Kehrer,1993). In the following $96 \mathrm{~h}$ from the beginning of poisoning, the concentration of MDA, the parameter that describes the intensity of lipid peroxidation, decreased (but not significantly in comparison with the untreated animals), what was obviously the consequence of the activation of the antioxidative system.

The process of lipid peroxidation itself is capable of increasing the process of free radical production, using NADPH as the electron donor.

Lipid peroxidation of cell membranes or the membranes of the endoplasmic reticulum, results in changes in the permeability for $\mathrm{Ca}^{2+}$ ions leading to the increase in their concentration in the cell, which eventually results in remarkable changes in $\mathrm{Ca}^{2+}$ dependent processes (Comporti, 1989).

Being an electron acceptor, $\mathrm{PQ}^{2+}$ builds complexes with numerous molecules, electron donors, neutral organic molecules, metal compounds, etc. The building of complexes between paraquat and poliphenol huminic acids strongly contributes to the deactivation of herbicides adsorbed in the soil (Gevao et al., 2000; Pacheco et al., 2003). Helate complexes between paraquat and heavy metal salts can be formed, e.g. $\mathrm{AgCl}, \mathrm{Hg}_{2} \mathrm{Cl}_{2}, \mathrm{HgCl}_{2}, \mathrm{PbJ}$, as well as with anions 
$\mathrm{Cu}_{2} \mathrm{Cl}_{6}{ }^{2-}, \mathrm{MnCl}_{4}{ }^{2-}, \mathrm{FeCl}_{4}{ }^{2-}$. Certain complexes with anions enable the longstanding herbicidal activity of paraquat (Amondham et al., 2006).

In the present research, an hour after application, natural and synthetic bentonite decreased the activity of CAT by $36 \%$ and $70.08 \%$, respectively, while their influence $192 \mathrm{~h}$ after administration is quite similar, being $51.74 \%$ and $46.04 \%$, respectively. In addition to this, both bentonites decreased lipid peroxidation in the first hour from the beginning of poisoning by $55 \%$ (natural bentonite) and $45 \%$ (synthetic bentonite). On the other hand, $192 \mathrm{~h}$ from the beginning of the intoxication the difference in their adsorbent efficacy was almost negligible $(\mathrm{Bn}=41.24 \%$ and $\mathrm{Bs}=43.75 \%)$.

By comparison of the relations catalase/lipid peroxidation (CAT/LP) in the group administered paraquat only and the control group, it was remarkable that the relation in the former group (CAT/LP=0.78) $24 \mathrm{~h}$ after the beginning of intoxication was 3.37 times lower than in the latter $(C A T / L P=2.63)$; this indicates a more intensive process of lipid peroxidation. This proves our hypothesis that paraquat induces the synthesis of peroxides that are not degraded by CAT, but that cooperate with superoxide anionic radical $\left(\mathrm{O}_{2}{ }^{-}\right)$leading to increased of lipid peroxidation and thus to synthesis of larger quantities of MDA.

It can be concluded that paraquat provokes oxidative stress that is considerable $1 \mathrm{~h}$ and $192 \mathrm{~h}$ after the beginning of intoxication with this herbicide.

Both natural and synthetic bentonite showed a protective activity in the period from 24 to $144 \mathrm{~h}$ after application, acting via external capacity of cationic exchange that is considered to be approximately $10 \%$. The absorption of paraquat is conditioned by the size of the molecule and its polarity, and is performed by the mechanisms of ionic exchange (ionic interaction and electrostatic interactions - van der Waals forces) (Pradas et al., 1996). The mechanism of adsorption is complicated and has yet to be described.

Both adsorbents expressed significant protective effects (approximately $50 \%) 1 \mathrm{~h}$ and $192 \mathrm{~h}$ after application, which indicates that both natural and synthetic bentonite acted as molecular sieves and thus suppressed the process of lipid peroxidation and the development of more intensive oxidative stress.

\footnotetext{
Address for correspondence:

Saša Ivanović

Faculty of Veterinary Medicine

Bul. oslobođenja 18

11000 Belgrade, Serbia

e-mail: salivano@vet.bg.ac.yu
}

\section{REFERENCES:}

1. Amondham W, Parkpian P, Polprasert C, Delaune RD, Jugsujinda A, 2006, Paraquat Adsorption, Degradation, and Remobilization in Tropical Soils of Thailand, J Environ Sci Health, 41, 5, 485507

2. Banat F, Al-Bashir B, Al-Asheh S and Hayajneh O, 2000, Adsorption of phenol by bentonite, Environ Pollut, 107, 391-8.

3. Beutler $E, 1982$, Catalase, In: Red cell metabolism, a manual of biochemical methods ed. (Beutler, E.) Grune and Stratton, Inc. 105-6. 
4. Bus JS, Gibson JE, 1984, Paraquat: model for oxidant-initiated toxicity, Environ Health Perspect 55, 37-46.

5. Comporti M, 1989, Three models of free radical-induced cell injury, Chem Biol Interact 72, 1-56.

6. Cope R, Bildfell R, Valentine B, White K, Cooper B, Oncken A, 2004, Fatal Paraquat Poisoning in Seven Portland, Oregon, Dogs, Vet Human Toxicol, 46, 5, 258-64.

7. Drabkin D, Austin H, 1935, Spectrophotometric studies preparations from washed blood cell, J Biol Chem, 112, 51-5.

8. Gevao B., Semplek KT, Jones KC, 2000, Bound pesticide residues in soils: a review Environ Pollut, $108,3-14$

9. Halliwe/l B, Gutterdge JM, 1999, Free Radicals in Biology and Medicine, 3rd edn Oxford University Press, New York.

10. Idid S, Lee C, 1996, Effects of Fuller's Earth and activated charcoal on oral absorption of paraquat in rabbits, Clin Exp Pharmacol Physiolog, 23, 8, 679-81.

11. Kehrer JP, 1993, Free radicals as mediators of tissue injury and disease, Critic Rev Toxicol, 23, 1, 21-48.

12. Kono Y, Fridovich I, 1982, Superoxide radical inhibits catalase, J Biol Chem, 257, 5751-4.

13. Liochev SI, Fridovich I, 1994, The role of $\mathrm{O}_{2}{ }^{--}$in the production of $\mathrm{HO}:$ in vitro and in vivo, Free Radic Biol Med, 29-33.

14. Lopez Lago A, Rivero Velasco C, Galban Rodriguez C, Marino Rozados A, Pineiro Sande N, Ferrer Vizoso E, 2002, Paraquat poisoning and hemoperfusion with activated charcoal, An Med Interna, 19, 6, 310-2.

15. Mates JM, Perez-Gomez C, De Castro IN, 1999, Antioxidant enzymes and human diseases, Clin Biochem, 32, 595-603.

16. Mollace V, lannone M, Muscoli C, Palma E, Granato T, Rispoli V, Nistico R, Rotiroti D, Salvemini D, 2003 , The role of oxidative stress in paraquat-induced neurotoxicity in rats: protection by nonpeptidyl superoxide dismutase mimetic, Neurosci Lett, 335, 163-6.

17. Okonek S et al., 1982, Successful treatment of Paraquat Poisoning: Activated Charcoal per os and »Continuous Hemoperfusion«, J Toxicol Clin Toxicol, 19, 8, 807-19.

18. PAN - Pesticide Action Network, Asia and Pacific, 2003, PARAQUAT, Summary.

19. Pacheco ML, Pena-Mendez EM, Havel J, 2003, Supramolecular interactions of humic acids with organic and inorganic xenobiotics studied by capillary electrophoresis, Chemosph, 51, 95-108.

20. Pradas EG, Sanchez MV, Perez MF, Viciana MS, 1996, Sorption of diuron, atrazine, MCPA, and paraquat on bentonite, humic acid and peat, Fresenius Environ Bull, 5, 178-84.

21. Suntres EZ, 2002, Role of antioxidants in paraquat toxicity, Toxicol, 180, 65-77.

22. Tomašević-Čanović Magdalena, Daković Aleksandra, Marković Vesna, Stojšić D., 2001, The effect of exchangeable cations in clinoptilolite and montmorillonite on the absorption of aflatoxin $B_{1}, J$ Serb Chem Soc, 66, 8, 555-61.

23. Traverso N, Menini S, Maineri EP, Patriarca S, Odetti P, Cottalasso D, Marinari UM, Pronzato MA, 2004, Malondialdehyde, a Lipoperoxidation-Derived Aldehyde, Can Bring About Secondary Oxidative Damage To Proteins, J Gerontol, 59, B890-95.

24. Uchida K, 2003, 4-Hydroxy-2-nonenal: a product and mediator of oxidative stress, Prog Lipid Res, 42, 4, 318-43.

25. Uchiyama $M$, Mihara $M$, 1978, Determination of malonaldehyde precursor in tissues by thiobarbituric acid test, Anal Biochem, 86, 271-8.

26. Valko M, Leibfritz D, Moncol J, Cronin MT, Mazur M, Telser J, 2007, Free radicals and antioxidants in normal physiological functions and human disease, Int J Biochem Cell Biol, 39, 44-84.

27. Valko M, Rhodes CJ, Moncol J, Izakovic M, Mazur M. 2006, Free radicals, metals and antioxidants in oxidative stress-induced cancer, Chem Biol Interact, 160. 1-40.

28. Vujaković Aleksandra, Daković Aleksandra, Lemić J., Radosavljević-Mihajlović Ana, TomaševićČanović Magdalena, 2003, Adsorption of inorganic anioniccontaminants on surfactant modified minerals, J Serb Chem Soc, 68, 11, 833-41.

29. Walcarius A, Mouchotte R, 2004, Efficient In Vitro Paraquat Removal via Irreversible Immobilisation into Zeolite Particles, Arch Environ Contam Toxicol, 46, 135-40. 


\section{PRIMENA BENTONITA KAO ADSORBENTA TOKOM OKSIDATIVNOG STRESA INDUKOVANOG PARAHVATOM} IVANOVIĆ S, BOROZAN SUNČICA, JEZDIMIROVIĆ MILANKA, ALEKSIĆ NEVENKA,
MILOVANOVIĆ MIRJANA, TOMAŠEVIĆ-ČANOVIĆ MAGDALENA i ĐURĐEVIĆ S

\section{SADRŽAJ}

U ovom radu su izneti rezultati proučavanja protektivnog efekta prirodnog i sintetskog bentonita tokom oksidativnog stresa indukovanog aplikacijom parahvata pacovima soja Wistar. Ogledne životinje su bile podeljene u četiri jednake grupe. Prva grupa pacova tretirana je samo parahvatom pomoću želudačne sonde. Jedan sat nakon aplikacije parahvata, pacovi druge i treće grupe su bili tretirani prirodnim ili sintetskim bentonitom, aplikovanim per os. Četvrta grupa pacova nije tretirana i služila je kao negativna kontrola. Eksperimentalne grupe životinja su bile tretirane jednom dnevno tokom osam uzastopnih dana. Uzorci krvi su uzimani 0, 1, 4, 6 i 8 dana nakon prvog tretmana.

Stepen oksidativnog stresa je procenjivan na osnovu aktivnosti enzima katalaze i na osnovu količine malondialdehida. Prirodni i sintetski bentonit ispoljili su protektivnu aktivnost smanjivanjem parametara oksidativnog stresa u periodu od 24 do 144 sata nakon aplikacije. Autori predpostavljaju da bentonit deluje kao molekularno sito suprimirajući proces lipidne peroksidacije. 